\title{
DNA Barcode of Black Capped White Eye Zosterops atricapilla (Aves: Zosteropidae) From Bengkulu Indonesia Based on Mitochondrial DNA COI Gene
}

\author{
Jarulis ${ }^{1, *}$ Ahmat Fakhri Utama ${ }^{2}$ Sipriyadi ${ }^{1}$ Santi Nurul Kamilah ${ }^{1}$ \\ ${ }^{1}$ Department of Biology, Faculty of Mathematics and Natural Sciences, Universitas Bengkulu, Kandang Limun, \\ Bengkulu 38112, Indonesia \\ ${ }^{2}$ Undergraduate Student, Department of Biology, Faculty of Mathematics and Natural Sciences, Universitas \\ Bengkulu, Kandang Limun, Bengkulu 38112, Indonesia \\ *Corresponding Author. Email: jarulis@unib.ac.id
}

\begin{abstract}
The study aims to determine the genetic character of Black-capped white-eye (Zosterops articapilla) using the mtDNA COI gene. Blood sample was collected from bird market in Bengkulu city and its DNA genome isolation and purification following the Protocols of Dneasy® Blood and Tissue Kit Cat no 69504 (50) based on the procedure of Spin-Column Protocol, Qiagen. We used polymerase chain reaction machine for amplification DNA template with specific primer (ZCOIF and ZCOIR). The results showed that there are nucleotide variations on five individual Black-capped white-eye with the COI gene sequence length $750 \mathrm{bp}$. We found of conservative site (C) is 743 sites, variations (V) seven sites, parsimony (Pi) four sites, singleton (S) three sites, and nucleotide base pairs of Zosterops atricapilla to adenine and thymine (AT) 55.9\% and guanine and cytosine (GC) $44.1 \%$. Fifth individual of Black-capped white-eye are separated with average intraspecies genetic distance $0.4 \%$, while its interspecific genetic distance is $3.47 \%$ and with the outgroup $12.1 \%$. We think, these COI gene sequences very important to quick identification and could be used as a forensic tool in preventing its trafficking.
\end{abstract}

Keywords: Conservation, Cytochrome Oxidase I, illegal trafficking, mtDNA, Zosterops atricapilla

\section{INTRODUCTION}

Almost all types of birds can be found in habitats located in nature. There are various types of birds that occupy every type of habitat ranging from the equator to the polar regions. Habitat can be one of the factors that affect the diversity of bird species due to the vegetation of plants in the habitat, thus supporting various types of bird activities [1]. The Black Capped White Eye Zosterops articapilla is one the bird species from Zosteropidae family. In Indonesia, there are \pm 35 types members of this family, while on the island of Sumatra there are seven species [2].

This mitochondrial DNA consists of proteincoding and non-coding genes [3]. Mitochondrial DNA, especially in animals, is a cytoplasmic genome that is passed down uniparentally (inherited only from the female parent gene) and does not recombine, so the sibling species will show a high degree of similarity [4]. In the last ten years, the COI gene (Cytochrome Oxidase subunit I) has been recognized and used in research as a DNA marker that is barcoding DNA to identify species in an animal, especially in bird animals [5]. This study aims to determine of genetic characters, single nucleotide polymorphisms, genetic distance, and phylogeny of Black Capped White Eye Zosterops articapilla from Bengkulu, Sumatra Indonesia.

\section{MATERIALS AND METHODS}

\subsection{Sample Collection}

Five bird Black-capped white-eye was collected from Panorama markets, Bengkulu City. We took 0.5-1 $\mathrm{ml}$ blood through pectorals veins using $1 \mathrm{ml} \mathrm{a}$ syringe. then, preserved with EDTA tube and stored in a $-20^{\circ} \mathrm{C}$ freezer. 


\subsection{DNA Isolation}

Total DNA isolation is performed using DNeasy Kit@ Blood and Tissue Kit paint no 69504 (50) based on Qiagen Spin-Column Protocol procedure with modification. DNA quality of isolation results are observed in agarose gel $1.2 \%$ using electrophoresis, then stored in the freezer $-20^{\circ} \mathrm{C}$ before amplification.

\subsection{DNA Amplification and Sequencing}

Target DNA replication in COI genes is carried out through the amplification process using polymerase chain reaction (PCR) techniques. The primer used for COI amplification is designed using tri primary programs available online. The sequence of COI genes used to design specific primers in this study comes from the complete genome of mitochondrial DNA of the Zosterops erythropleurus type found in GenBank with access code NC 027942 and the length of the COI sequence used is 1550 base pairs where 2 types of primers are used namely ZCOIF (5'TTCTGATTCTTTGGCCAT CC-3') and ZCOIR (5'GTTGGAAGGCTT TGCGTTTA-3'). The mixture of amplification reactions with PCR technique (total $25 \mu \mathrm{l}$ ) consists of ddH2O $9.8 \mu \mathrm{l}$, Qs buffer $5.0 \mu \mathrm{l}$, enhancer Qs $5.0 \mu \mathrm{l}$, dNTP $1.0 \mu \mathrm{l}$, primary forward $1.0 \mu \mathrm{l}$, reverse primer $1.0 \mu \mathrm{l}$, DNA template $2 \mu \mathrm{l}$, and Taq polymerase $0.2 \mu \mathrm{l}$. The condition of the PCR machine during amplification is as follows; preternatural temperature $95^{\circ} \mathrm{C}$ for 5 minutes, denaturation $94^{\circ} \mathrm{C} 1$ minute, annealing $51^{\circ} \mathrm{C}$ 45 seconds, elongation $72^{\circ} \mathrm{C} 1$ minute, past elongation $72^{\circ} \mathrm{C} \quad 6$ minutes, and cooling $4^{\circ} \mathrm{C} 10$ minutes. The number of cycles of the denaturationelongation stage is 35 times. The DNA $(3.0 \mu \mathrm{l})$ of PCR results is visualized on a $1.2 \%$ agarose gel with an electrophoresis device and the result is photographed with a UV transilluminator $(\lambda=302$ $\mathrm{nm})$. PCR products with good tape are sent to $\mathrm{pt}$ company. First Base in Singapore for sequencing.

\subsection{Data Analysis}

Forward and reverse sequencing results are edited by alignment using Clustal W mega 6.0 program [6]. BIOEDIT software version 7.0.9 [7], used to edit the sequence of COI genes, and visualization of electrograms and their nucleotide base sequences. Each individual's COI gene sequence is aligned with the GenBank COI gene through the Barcode of Life Data System (BoLD System) to see the similarities of the samples tested. The genetic distance between individuals is calculated using the 2-parameter Kimura (K2P) method [8]. The phylogenic tree was reconstructed using the Neighbor-Joining (NJ) method with 1000 replication times [7]. The COI gene sequence of bird from GenBank was downloaded and included in the analysis of the reconstruction of the phylogenic tree.

\section{RESULT AND DISCUSSION}

\subsection{DNA Size}

The DNA sequence length of the CO1 gene targeted in the study was designed with a specific primer of $750 \mathrm{bp}$ (Figure 1). The results of PCR products with bright band are continued to the sequencing process stage to obtain a sequence of $\mathrm{CO} 1$ genes of Zosterops atricapilla. Based on the results of sequencing obtained the length of the nucleotide sequence of all individuals $(n=5)$ for the forward range between 752 and $763 \mathrm{bp}$ and reverse 748 and $758 \mathrm{bp}$. Then followed by editing using Bioedit and MEGA 6 software, the sequence used for the data analysis stage is $750 \mathrm{bp}$.

The length of the DNA sequence of the CO1 gene obtained in this study differs from some previous studies. In the same order, the Order of Passeriformes obtained a sequence of CO1 along $1,517 \mathrm{bp}$ in the species Hirundo rustica [21].

Jarulis et al. [11] obtained the length of CO1 gene sequences in seven species of Indonesian hornbills 746 bp. Astuti et al. [20] found a sequence of DNA of Sumbawa srigunting birds $795 \mathrm{bp}$. In general, the length of the CO1 gene used for barcodes is about half of the total length located at the beginning of the CO1 gene in all animal species [9].

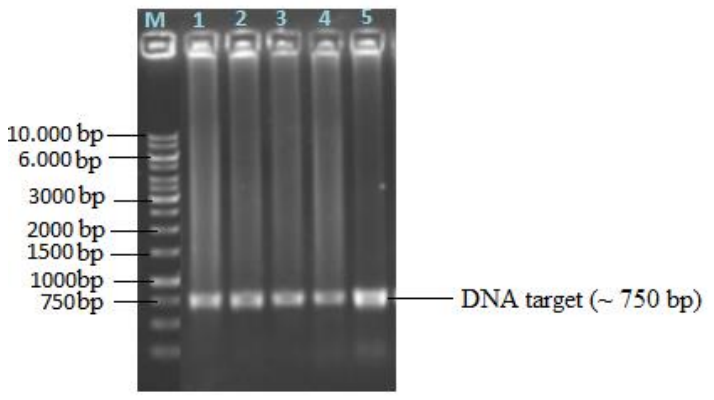

Figure 1. Mitochondrial DNA CO1 Gene Band Zosterops atricapilla. Description: $\mathrm{M}=$ Marker, $1=$ ZACO1 (1st Ind.), 2 = ZACO2 (2nd Ind.), $3=$ $\mathrm{ZACO} 3$ (3rd Ind.), $4=\mathrm{ZACO} 4$ (4th Ind.), $5=$ ZACO5 (5th Ind.)

Based on the description of the results of the above study, it can be concluded that the sequence of $\mathrm{CO} 1$ genes obtained in this study generally appears longer, except for the CO1 gene of the drongo bird. 
However, it is still included in the length of the sequence that is often used in the barcode of animal species.

\subsection{Species Identification}

The sequence of nucleotides obtained in this study was compared to the nucleotide sequences contained in the GenBank data to determine the similarity of the samples tested. Based on bold system results, the highest similarity of the entire sample $(n=5)$ ranged between 97.88 and $98.94 \%$, and the lowest similarity ranged between 95.24 and $96.30 \%$ (Table 1). Types of Zosterops spp. identified by the above similarities are Zosterops erythropleurus, Z. japonica, and Z. lateralis. All species Zosterops spp. identified from GenBank originating outside Indonesia. These results suggest that a sequence of Zosterops atricapilla- nucleotides are not yet available in GenBank data.

The difference in the value of similarities between animal species has a threshold value of more than $3.0 \%$ [10]. In Jarulis et al. [10] all individuals tested had a similar value of less than $97.0 \%$. While Johnsen et al. research [11] got a Scandinavian bird similarity value of more than $97.0 \%$.

Based on the results of the similarity comparison it is known that generally, the Zosterops atricapilla sample in this study has a similarity rate of more than 97.0\% except in Zosterops lateralis which is less than 97.0\%. However, the Zosterops atricapilla sequence in this study differs in species and not yet listed in
GenBank data. Therefore, the sequence obtained in this study is new information so that it can be a reference to identify birds of black capped white eye in Indonesia.

\subsection{Nucleotides Variation and Composition}

Variations and composition of individual intraspecies nucleotides Zosterops atricapilla $(\mathrm{n}=5)$ are shawn in Table 2. Based on the CO1 gene alignment results using the Clustal $\mathrm{W}$ model in MEGA 6 software it is known that all individuals Zosterops atricapilla have a number of conservative nucleotide sites (C) 743 sites $(99.06 \%)$, variations (V) 7 sites $(0.93 \%)$, parsimony (Pi) 3 sites $(0.4 \%)$, and singletons (S) 4 sites $(0.53 \%)$. Total variable sites ( $\mathrm{V}$ and $\mathrm{Pi}$ ) 10 sites $(1.33 \%$ ). In table 2. it is shown that the nucleotide composition of each individual Zosterops atricapilla obtained a difference. The highest nucleotide composition of all Zosterops atricapilla individuals is Thymine $(\mathrm{T})$ with a range of 28.0 and $28.1 \%$ and the lowest is Guanine $(\mathrm{G})$, in the range of 16.5 and $16.7 \%$. The pairs of Adenine and Thymine nucleotides (AT) of all individuals, Zosterops atricapilla $(\mathrm{n}=5)$ was highest than $(55.9 \%)$ and Guanine and Cytosine (GC) $44.1 \%$.

The composition obtained from this study differs from previous research. Other studies on falcons showed a difference in composition comparison of $\mathrm{AT}<\mathrm{GC}$ which is $48.9 \%$ and $51.1 \%$ [12]. Generally, the GC content in vertebrates ranges from $40-45 \%$ [13].

Table 1. The species similarity of the black capped white eye (Zosterops atricapilla) based on BOLD System results

\begin{tabular}{llll}
\hline \multirow{2}{*}{ Sample } & \multicolumn{2}{c}{ BOLD System } & \multirow{2}{*}{ Country } \\
\cline { 2 - 4 } & Species & Similarity (\%) & \\
\multirow{2}{*}{ Zosterops atricapilla 1} & Z. erythropleurus & 98.94 & China \\
& Z. japonicus & 97.35 & China \\
& Z. lateralis & 96.30 & New Zealand \\
\hline \multirow{2}{*}{ Zosterops atricaiplla 2} & Z. erythropleurus & 97.88 & China \\
& Z. japonicus & 96.30 & China \\
& Z. lateralis & 95.24 & New Zealand \\
\hline \multirow{2}{*}{ Zosterops atricapilla 3 } & Z. erythropleurus & 98.94 & China \\
& Z. japonicus & 97.35 & China \\
& Z. lateralis & 96.30 & New Zealand \\
\multirow{2}{*}{ Zosterops atricapilla 4} & Z. erythropleurus & 98.94 & China \\
& Z. japonicus & 97.35 & China \\
& Z. lateralis & 96.30 & New Zealand \\
\hline \multirow{2}{*}{ Zosterops atricapilla 5 } & Z. erythropleurus & 97.88 & China \\
& Z. japonicus & 96.30 & China \\
& Z. lateralis & 95.24 & New Zealand \\
\hline
\end{tabular}




\subsection{Single Nucleotide Polymorphism (SNP)}

The results of alignment the nucleotide sequence of the $\mathrm{CO} 1$ gene in the Zosterops atricapilla species found the single nucleotide polymorphism (SNP) to be the differentiation between individuals (Table 3). Based on the search results of SNP obtained 7 specific nucleotide sites that became differentiating between 5 individuals Zosterops atricapilla studied. SNP sites were obtained evenly distributed across sequences ranging from sites 9 and 749 of the CO1 gene sequence length to $750 \mathrm{bp}$. Variations in CO1 gene sequences can be used to distinguish between species close to all other animal notes, thus suggesting that the diversity of $\mathrm{CO} 1$ gene sequences is potentially a barcode of animal species [14].

\subsection{Genetic Distance}

Determination of genetic distance using the Kimura 2-parameter model (Table 4). In Table 4. it appears that the minimum genetic distance value between individuals $(\mathrm{n}=5)$ is $0.000(0.0 \%)$, maximum $0.008(0.8 \%)$ and an average of $0.004(0.4 \%)$. While the genetic distance between Zosterops atricapilla and Zosterops spp. from GenBank data as follow; maximum distance of $0.053(5.3 \%)$, a minimum distance of $0.019(1.9 \%)$, and an average distance of $0.034(3.4 \%)$. Genetic distance between the genus Zosterops (Zosterops atricapilla and Zosterops spp. GenBank) with Yuhina spp. maximum distance is $0.141(14.1 \%)$, minimum is $0.104(10.4 \%)$ and an average of $0.121(12.1 \%)$. Groves [15] said that the difference in nucleotides and genetic distances of $3 \%$ between populations is a separate species.

The results showed that between Zosterops atricapilla from Indonesia and Zosterops sp. species from GenBank are different species because it has a genetic distance of $3.47 \%$ although it is incorporated into the same genus.

The genetic distance to accurately identify a genus must be more than 5\% [16]. The lower the genetic distance value in an individual indicates that the individual has a closer kinship while the genetic distance is high than has a long kinship relationship [17].

Table 2. Conservative and varied site of COI Zosterops atricapilla genes from Indonesia

\begin{tabular}{|c|c|c|c|c|c|c|c|c|}
\hline \multirow{2}{*}{ Species } & \multirow{2}{*}{ Conserved } & \multicolumn{3}{|c|}{ Site Variation } & \multicolumn{4}{|c|}{ Composition Nucleotide (\%) } \\
\hline & & Variable & $\mathbf{P i}$ & $\mathbf{S}$ & $\mathbf{A}$ & $\mathbf{T}$ & $\mathbf{G}$ & C \\
\hline Zosterops atricapilla 1 & & & & & 27.9 & 28.1 & 16.5 & 27.5 \\
\hline Zosterops atricapilla 2 & & & & & 27.6 & 28.1 & 16.7 & 27.6 \\
\hline Zosterops atricapilla 3 & 743 & 7 & 3 & 4 & 27.9 & 28.1 & 16.5 & 27.5 \\
\hline Zosterops atricapilla 4 & & & & & 27.9 & 28.1 & 16.5 & 27.5 \\
\hline Zosterops atricapilla 5 & & & & & 27.9 & 28.0 & 16.5 & 27.6 \\
\hline
\end{tabular}

Note: $\mathrm{Pi}=$ Parsimony-informative site, $\mathrm{S}=$ Singleton site, $\mathrm{A}=$ Adenine, $\mathrm{T}=$ Thymine, $\mathrm{G}=$ Guanine, $\mathrm{C}=\mathrm{Cytosine}$

Table 3. SNP among individuals Zosterops atricapilla based on CO1 gene $750 \mathrm{bp}$

\begin{tabular}{lccccccc}
\hline \multicolumn{1}{c}{ Individual } & \multicolumn{7}{c}{ Number Sequence } \\
\cline { 2 - 8 } & $\mathbf{9}$ & $\mathbf{1 0}$ & $\mathbf{5 7 0}$ & $\mathbf{5 9 1}$ & $\mathbf{6 2 1}$ & $\mathbf{7 4 7}$ & $\mathbf{7 4 9}$ \\
\hline Zosterops erytropleurus & $\mathrm{C}$ & $\mathrm{T}$ & $\mathrm{C}$ & $\mathrm{A}$ & $\mathrm{C}$ & $\mathrm{C}$ & $\mathrm{A}$ \\
Zosterops atricapilla 1 &. &. & $\mathrm{~T}$ &. &. &. &. \\
Zosterops atricapilla 2 & $\mathrm{~T}$ & $\mathrm{C}$ &. & $\mathrm{G}$ &. & $\mathrm{T}$ & $\mathrm{C}$ \\
Zosterops atricapilla 3 &. &. &. &. & $\mathrm{~T}$ &. &. \\
Zosterops atricapilla 4 &. &. & $\mathrm{~T}$ &. &. &. &. \\
Zosterops atricapilla 5 & $\mathrm{~T}$ & $\mathrm{C}$ &. &. &. &. &. \\
\hline
\end{tabular}


Table 4. Genetic distance intraspecies Zosterops atricapilla, interspecies Zosterops spp. and intergenus Zosteropidae

\begin{tabular}{lccc}
\hline Genetic distance & Min. & Max. & Average \\
\hline Intraspecies Zosterops atricapilla & $0.0 \%$ & $0.8 \%$ & $0.4 \%$ \\
Interspecies Zosterops atricapilla versus Zosterops spp. & $1.9 \%$ & $5.3 \%$ & $3.4 \%$ \\
Intergenus Zosterops spp. versus Yuhina spp. & $10.4 \%$ & $14.1 \%$ & $12.1 \%$ \\
\hline
\end{tabular}

\subsection{Phylogeny}

The results of Zosterops atricapilla $(\mathrm{n}=5)$ phylogenetic tree reconstruction from Indonesia using a neighbor-joining model with 1000 bootstrap replication are shown in Figure 2. The results of the analysis showed they were of 3 separate groups. In phylogenetic trees obtained bootstrap value of Zosterops atricapilla Indonesia grouping ranges from $63-100 \%$. From Figure 2 the bootstrap value belongs to a stable category, except for Zosterops atricapilla 1 and 4 which have a bootstrap value of $63 \%$.
Furthermore, Dharmayanti [18] states that branch relationships in the phylogenic section describe the level at which different sequences are interconnected. Two very similar sequences will be located in one branch. Different sequences will be located in different branches. The addition of outgroups can be done to know the level of kinship. The selection of outgroup sequences that go too far is likely to cause tree construction to go wrong due to more distinction between the outgroup sequence and the other sequences.

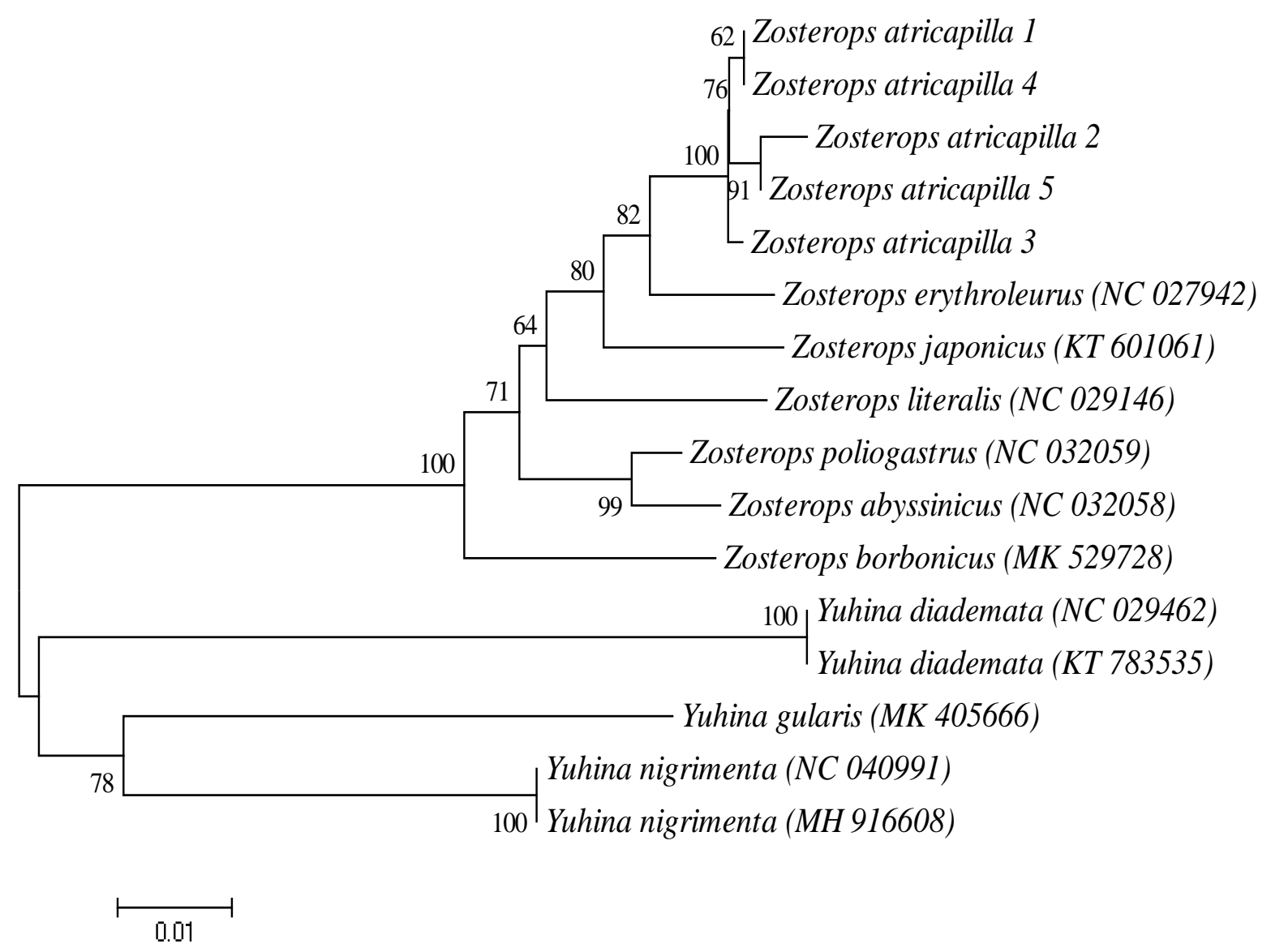

Figure 2. Neighbor Joining phylogenetic tree Zosterops atricapilla (5 individual) reconstructed using K2P model with 1000 bootstrap based on mtDNA COI gene (750 bp). 


\section{CONCLUSION}

Our study suggests that Zosterops atricapilla genetic character is different to another Zosterops. We observed 743 conservative sites (C), seven variable $(\mathrm{V})$ sites, four parsimony $(\mathrm{Pi})$ sites, three singleton (S) sites and the highest nucleotide composition is Thymine $(\mathrm{T})$ ranged between 28.0 and $28.1 \%$ and the lowest is Guanine $(\mathrm{G})$ ranged between 16.5 and $16.17 \%$. While nucleotide base pairs composition of Adenine and Thymine (AT) higher $(55.9 \%)$ than Guanine and Cytosine $(44.1 \%)$. There were seven specific nucleotide sites (SNP) of Zosterops atricapilla COI gene with length $725 \mathrm{bp}$. Average genetic distance intraspecies is $0.8 \%$.

\section{ACKNOWLEDGMENTS}

We would like to thank Drs. Choirul Muslim, SU., Ph.D., and Santi Nurul Kamilah, S.Si., M.Si. for assisting in the improvement of this article. We also express our appreciation to friends in the zoology laboratory who have helped during the research.

\section{REFERENCES}

[1] N. S. Hamzati, Aunurohim, Keanekaragaman burung di beberapa tipe habitat di bentang alam Mbeliling bagian barat, Flores, Jurnal Sains dan Seni Pomits 2(2) (2013) 121-126. [In Bahasa Indonesia]

[2] J. Iskandar, Jenis burung, Jakarta, Anggota Ikapi, 1989. [In Bahasa Indonesia]

[3] W-H. Li, D. Graur, Fundamentals of Molecular Evolution, Folia Primatol 69 (1991) 171-174.

[4] R.A. Syafrina, Penggunaan DNA barcode sebagai alternatif identifikasi spesies Udang Mantis, Undergraduate Thesis, Institut Pertanian Bogor, 2011. [In Bahasa Indonesia]

[5] P.D.N. Hebert, S. Ratnasingham, J.R. deWaard Hebert, Barcoding animal life: cytochrome C oxidase subunit 1 divergences among closely related species, Proceeding of The Royal Society London 270 (2003) 96-99. DOI: 10.1098/Rsbl.2003.0025.

[6] K.Tamura, G. Stecher, D. Peterson, A. Filipski, S. Kumar, MEGA6: Molecular Evolutionary Genetics Analysis Version 6.0', Molecular Biology and Evolution, 30(12) (2013) 27252729. DOI: 10.1093/Molbev/Mst197.
[7] T.A. Hall, Bioedit: a user-friendly biological sequence alignment editor and analysis program for windows 95/98/Nt, Nucleic Acids Symposium Series 41 (1999) 95-98.

[8] M. Kimura, A simple method for estimating evolutionary rates of base substitutions through comparative studies of nucleotide sequences, Journal of Molecular Evolution 16(2) (1980) 111-120. DOI:10.1007/Bf01731581.

[9] X-P. Zhou, C-T. Yao, Q-X. Fang, W-Z. Fang, $\mathrm{X}-\mathrm{L}$. Chen, Complete mitochondrial genomes render the Night Heron genus Gorsachius nonmonophyletic, Journal of Ornithology 157(2) (2015) 505-513. DOI: 10.1007/S10336-0151297-Z.

[10] P.D.N. Hebert, A. Cywinska, S.L. Ball, J.R. DeWaard, Biological identifications through DNA barcodes, Proceedings of The Royal Society B: Biological Sciences 270(1512) (2003) 313-321. DOI: 10.1098/Rspb.2002.2218.

[11] Jarulis, D.D. Solihin, A. Mardiastuti, L.B. Prasetyo, DNA barcode of seven Indonesian Hornbills Species (Aves: Bucerotidae) based on mitochondrial DNA cytochrome oxidase subunit I, Hayati Journal of Biosciences 25(4) (2018) 178-187. DOI: 10.4308/Hjb.25.4.178.

[12] A.Johnsen, E. Rindal, P.G.P. Ericson, D. Zuccon, K.C.R. Kerr, M.Y. Stoeckle, J.T. Lifjeld, 'DNA Barcoding of Scandinavian Birds Reveals Divergent Lineages in Trans-Atlantic Species, Journal of Ornithology 151(3) (2010) 565-578. DOI: 10.1007/S10336-009-0490-3.

[13] M.S.A. Zein, Barkoding DNA burung Elang (Famili Accipitridae) di Indonesia, Jurnal IlmuIlmu Hayati 17(2) (2018) 165-173. DOI:10.14203/Beritabiologi.V17i2.3108. [In Bahasa Indonesia]

[14] N. Sueoka, On the genetic basis of variation and heterogeneity of DNA base composition, Genetics 108(1284) (1983) 411-414. DOI: 10.1039/An9830800411.

[15] P.D.N. Hebert, E.H. Penton, J.M. Burns, D.H. Janzen, W. Hallwachs, Ten species in one: DNA barcoding reveals cryptic species in the neotropical skipper butterfly Astraptes fulgerator, Proceedings of The National Academy of Sciences of The United States of 
America 101(41) (2004) 14812-14817. DOI: 10.1073/Pnas.0406166101.

[16] C.P. Groves, Primate taxonomy, Smithsonian Institution Press, Washington DC, 2001.

[17] J.Waugh, DNA barcoding in animal species: progress, potential and pitfalls, Bioessays 29(2), (2007) 188-197. DOI: 10.1002/Bies.20529.

[18] R. Putri, Identifikasi keragaman gen cytochrome oxidase subunit I (COI) DNA mitokondria pada ayam lokal Indonesia, Undergraduate Thesis, Institut Pertanian Bogor, 2013. [In Bahasa Indonesia]

[19] N.L.P.I Dharmayanti, Filogenetika molekuler: metode taksonomi organisme berdasarkan sejarah evolusi, Wartazoa 212011 1-10.

[20] D. Astuti, H. Ashari, M. Irham, S. Sulandari, Analisis gen cytochrome oxydase-1 (COI) untuk konfirmasi status taksonomi burung Srigunting Sumbawa (Dicrurus, Dicruridae), Zoo Indonesia 26(1) (2017) 44-51. [In Bahasa Indonesia]

[21] R. Dor, R.J. Safran, F.H. Sheldon, D.W. Winklerand, I.J. Lovette, Phylogeny of the genus Hirundo and the Barn Swallow subspecies complex, Molecular Phylogenetics and Evolution 56(1) (2010) 409-418. DOI: 10.1016/j.ympev.2010.02.008. 